\title{
KOMPETENSI GURU DALAM PEMBELAJARAN BERBASIS PENDIDIKAN KARAKTER UNTUK ANAK USIA DINI
}

\author{
Rita Mariyana, M.Pd ${ }^{1}$ \\ rita_upi@yahoo.co.id
}

\begin{abstract}
The literature reveals that learning in early childhood emphasizes the variety of potential in terms of development , the formation of attitudes and behavior and the development of basic knowledge and skills children need to adjust to the environment and to face the development tasks further study. The success of a nation in obtaining tujuanya determined by thequality of its human resources. " Great nation can be seen from the quality / character of the nation (human ) itself". This study aimed to describe the competence of teachers in character education based learning in early childhood. The study used a descriptive method, by using purposive sampling in Kindergarten teachers.
\end{abstract}

Keywords: Human Resources, Kindegarten teacher, Nation Building.

${ }^{1}$ Dosen PGPAUD Universitas Pendidikan Indonesia 
Kata Kunci : Kompetensi, Guru, Pendidikan Karakter, Anak.

\section{PENDAHULUAN}

Undang-Undang Republik Indonesia (UURI) Nomor 14 Tahun 2005 tentang Guru dan Dosen BAB I mengenai ketentuan umum pasal 1 disebutkan bahwa yang dimaksud dengan : "Guru adalah pendidik profesional dengan tugas utama mendidik, mengajar, membimbing, mengarahkan, melatih, menilai, dan mengevaluasi peserta didik pada pendidikan anak usia dini jalur pendidikan formal, pendidikan dasar, dan pendidikan menengah.” (Ayat 1). "Profesional adalah pekerjaan atau kegiatan yang dilakukan oleh seseorang dan menjadi sumber penghasilan kehidupan yang memerlukan keahlian, kemahiran, atau kecakapan yang memenuhi standar mutu atau norma tertentu serta memerlukan pendidikan profesi." (Ayat 4). "Kompetensi adalah seperangkat pengetahuan, keterampilan dan perilaku yang harus dimiliki, dihayati, dan dikuasai oleh guru atau dosen dalam melaksanakan tugas kerpofesionalan.” (Ayat 10).UndangUndang Republik Indonesia Nomor 20 Tahun 2003 tentang Sistem Pendidikan Nasional (UUSPN) pada bagian ketujuh tentang Pendidikan Anak Usia Dini (PAUD) pasal 28 pada ayat tiga (3) menyebutkan bahwa "Pendidikan anak usia dini pada jalur pendidikan formal berbentuk Taman Kanakkanak (TK), Raudatul Athfal (RA), atau bentuk lain yang sederajat". Pada penjelasan pasal 28 ayat (3) dijelaskan bahwa Taman kanak-kanak (TK) menyelenggarakan pendidikan untuk mengembangkan kepribadian dan potensi diri sesuai dengan tahap perkembangan peserta didik. Raudhatul Athfal (RA) menyelenggarakan pendidikan keagamaan Islam yang menanamkan nilai-nilai keimanan dan ketakwaan kepada peserta didik untuk mengembangkan potensi diri seperti pada taman kanak-kanak.

Anak usia 4-6 tahun merupakan bagian anak usia dini yang berada pada rentangan usia lahir sampai 6 tahun. Pada usia ini secara terminologi disebut sebagai anak usia prasekolah. Taman Kanak-Kanak (TK) merupakan salah satu jenjang pendidikan prasekolah pada jalur pendidikan formal. Anak usia prasekolah antara rentang 4-6 tahun ini, biasanya sedang menempuh jenjang pendidikan formal ini, baik yang diselenggarakan oleh pemerintah (Negeri) ataupun pihak swasta. Pada usia TK (4-6 tahun), merupakan masa peka bagi anak. Anak mulai sensitif untuk menerima berbagai upaya perkembangan seluruh potensi. Masa peka adalah masa terjadinya pematangan fungsi-fungsi fisik dan psikis yang siap merespon stimulasi yang diberikan oleh lingkungan. Masa ini merupakan masa untuk meletakan dasar pertama dalam mengembangkan kemampuan fisik, kognitif, bahasa, sosial emosional, konsep diri, disiplin, kemandirian, seni, moral, dan nilai-nilai agama.

Salah satu masalah yang paling pundamental dalam kegiatan pendidikan anak usia dini khususnya di Taman Kanakkanak (TK) adalah kecenderungan guru yang masih kurang mampu merancang program pembelajaran yang berbasis karakter yang tepat bagi tumbuhkembang anak, selain itu masih ada guru TK yang belum mengenyam pendidikan ataupun pelatihan terkait dengan pendidikan karakter untuk anak usia dini sehingga banyak guru yang belum memiliki daya kreativitas untuk menjadikan pembelajaran bagi anak menyenangkan dan menghibur, sehingga tidak salah apabila permasalahan di atas bermuara pada meningkatnya jumlah anak- 
anak yang mengalami kejenuhan dan mogok belajar pada saat melanjutkan studi pada jenjang selanjutnya (Agustin,2009).

\section{LANDASAN TEORI}

\section{- Kompetensi Guru}

Istilah kompetensi (competence) dalam bahasa Indonesia diartikan sebagai kecakapan atau kemampuan. Terdapat beberapa makna dari kompetensi, diantaranya pendapat para ahli sebagai berikut.

1. "Teacher competency is the ability of a teacher to responsibility perform has or her duties appropriately". (Uzer Usman, 2000). Kemampuan seorang guru dalam melaksanakan kewajiban-kewajiban secara bertanggung jawab dan layak.

2. “...is a knowledge, skills, and abilities or capabilities that a person achieves, which become part of his or her being to the exent he or she can satisfactorily perform particular cognitive, afective, and psychomotor behaviors". (McAshan, 1981) dalam Mulyasa (2002).

$\begin{array}{lcr}\text { Kompetensi } & \text { diartikan } & \text { sebagai } \\ \text { pengetahuan, } & \text { ketrampilan } & \text { dan }\end{array}$ kemampuan yang dikuasai olehseseorang yang telah menjadi bagian dari dirinya, sehingga ia dapat melakukan perilakuperilaku kognitif, afektif dan psikomotor dengan sebaik-baiknya.

3. Kompetensi adalah seperangkat pengetahuan, keterampilan dan perilaku yang harus dimiliki, dihayati, dan dikuasai oleh guru atau dosen dalam melaksanakan tugas kerpofesionalan.

Guru merupakan jabatan atau profesi yang memerlukan keahlian khusus sebagai guru. Pekerjaan ini tidak dapat dilakukan oleh orang yang tidak memiliki keahlian untuk melakukan kegiatan atau pekerjaan sebagai guru. Untuk menjadi guru diperlukan syarat-syarat khusus, apalagi sebagai guru yang profesional harus menguasai betul seluk beluk pendidikan dengan berbagai ilmu pengetahuan lainnya yang perlu dibina dan dikembangkan melalui masa pendidikan tertentu atau pendidikan prajabatan (Usman, 2000:5). Dalam Kamus Besar Bahasa Indonesia, guru diartikan sebagai orang yang pekerjaannya mengajar. Akan tetapi pada pelaksanaanya dalam kegiatan pendidikan tugas guru tentunya bukan hanya mengajar yang berorientasi pada pengembangan kecakapan yang berdimensi ranah cipta saja akan tetapi guru turut juga mengembangkan ranah rasa dan karas para peserta didik. Sebab, dalam perspektif psikologi pendidikan mengajar pada prinsipnya berarti proses perbuatan seseorang (guru) yang menjadikan orang lain (peserta didik) belajar, dalam arti mengubah seluruh dimensi perilakunya. (Syah, 1999:222). Sedangkan, menurut Surya (2003:134-135) ditinjau dari sudut pandang psikologis guru adalah sebagai : (1) pakar psikologi pendidikan, artinya seseorang yang memahami psikologi pendidikan dan mampu mengamalkannya dalam melaksanakan tugasnya sebagai pendidik; (2) seniman dalam hubungan antar manusia (artist in human relations), artinya guru adalah orang yang memiliki kemampuan menciptakan suasana hubungan antar manusia khususnya dengan para siswa sehingga dapat mencapai tujuan pendidikan; (3) pembentuk kelompok (group builder), yaitu mampu menciptakan kelompok dan aktivitas-aktivitas untuk mencapai tujuan pendidikan; (4) catalytic agent atau inovator, yaitu orang yang mampu menciptakan suatu pembaharuan untuk membuat suatu hal yang lebih baik; dan (5) petugas kesehatan mental (mental hygiene worker),artinya guru bertanggung jawab bagi terciptanya kesehatan mental para siswa.

Untuk mempertegas peran dan fungsi guru dalam kegiatan pendidikan dan 
pengajaran Makmun (2000:23) menjelaskan bahwa dalam kegiatan pendidikan guru yang ideal dapat bertugas dan berperan sebagai (1) konservator (pemelihara) sistem nilai yang merupakan sumber norma kedewasaan dan inovator (pengembang) sistem nilai ilmu pengetahuan; (2) transmitor (penerus) sistem-sistem nilai tersebut kepada sasaran didik; (3) transformator (penerjemah) sistem-sistem nilai tersebut melalui penjelmaan dalam pribadinya dan perilakunya melalui proses interaksinya dengan sasaran didik; dan (4) organisator (penyelenggara) terciptanya proses edukatif yang dapat dipertanggungjawabkan baik secara formal ataupun secara moral. Sedangkan dalam kegiatan pengajaran, guru berperan dan bertugas sebagai (1) perencana (planner) yang harus mempersiapkan perangkat-perangkat yang akan dipergunakan dalam kegiatan pengajaran; (2) pelaksana (organizer) yang harus menciptakan situasi, memimpin, merangsang, menggerakan, dan mengarahkan kegiatan pembelajaran sesuai dengan rencana; dan (3) penilai (evaluator) yang harus mengumpulkan, menganalisis, menafsirkan, dan akhirnya harus memberikan pertimbangan atas keberhasilan pembelajaran.

\section{- Pendidikan Karakter untuk Anak Usia Dini}

\section{Pengertian Karakter}

Karakter saat ini tengah menjadi perbincangan yang menarik dan menjadi pembahasan dalam setiap bidang khususnya dalam bidang pendidikan karena pendidikan merupakan tempat transformasi ilmu pengetahuan dari generasi ke generasi, sebagai orang yang terlibat dalam dunia pendidikan tentu harus memahami apa yang dimaksud dengan karakter. secara bahasa, karakter berasal dari bahasa Yunani yaitu charassein yang artinya mengukir, apabila kita mencoba untuk memahami lebih dalam apa yang dimaksud dengan "mengukir" dapat kita temukan bahwa hasil ukiran yang baik dan pada benda yang baik maka akan terus melekat, tidak mudah usang.

Pengertian karakter banyak diungkapkan oleh para ahli. Menurut para ahli seperti Hornby dan Parnwell mengungkapkan bahwa karakter adalah kualitas mental atau moral, kekuatan moral, nama atau reputasi. McCarrol (Megawangi, 2004:5) mengungkapkan bahwa karakter terbentuk karena latihan setiap hari, hal tersebut sesuai dengan arti karakter secara bahasa yaitu "mengukir", dalam kegiatan mengukir dibutuhkan proses, keahlian serta ketelitian dari pengukir sehingga menghasilkan ukiran yang kokoh begitupun dengan proses pembentukan karakter individu yang harus dilakukan sejak dini sehingga karakter tersebut melekat kuat dalam diri individu. Goleman (1995) menyatakan bahwa karakter merupakan kecerdasan emosional, dan Mulyana (2004:3) mempertegas apa yang dimaksud dengan karakter, bahwa karakter merupakan "sebuah pola baik itu pikiran, sikap, maupun tindakan yang melekat pada diri seseorang dengan sangat kuat dan sulit dihilangkan", walaupun pada pengertian sebelumnya karakter sulit untuk diubah bukan berarti seseorang yang memiliki karakter negatif tidak dapat diubah menjadi karakter positif hanya saja membutuhkan waktu yang relatif lama dan dari beberapa pengertian di atas dapat disimpulkan bahwa yang dimaksud dengan karakter adalah kualitas moral seseorang dalam bertindak dan berprilaku sehingga menjadi ciri khas individu dan dapat membedakan dirinya dengan individuindividu lainnya.

\section{Pendidikan karakter}

Pendidikan karakter terdiri dari dua kata yang apabila dipisahkan memiliki makna masing-masing, pendidikan adalah selalu berkaitan dengan hubungan sosial 
manusia, manusia sejak lahir tidak dapat hidup sendiri tetapi membutuhkan orang lain sedangkan karakter lebih bersifat subjektif hal tersebut dikatakan demikian karena berkaitan dengan stuktur antropologis manusia dan tindakannya dalam memaknai kebebasan. (Megawangi, 2004:9).

Pendidikan karakter harus diberikan di Sekolah-sekolah khususnya pendidikan anak usia dini karena pembentukan karakter tidak dapat dilakukan secara cepat tetapi membutuhkan proses yang cukup panjang sehingga karakter positif tersebut dapat melekat kuat dalam jiwa individu bagaikan ukiran yang tidak akan usang terrmakan waktu, konteks pendidikan karakter di sekolah mampu menjiwai dan mengarahkan penghayatan pendidikan karakter yang realistis, konsisten dan integral. Menurut Lickona T (1992) terdapat lima metode yang dapat dipertimbangkan untuk digunakan dalam mengembangkan program pendidikan karakter di sekolah yaitu mengajarkan, keteladanan, menentukan prioritas, praksis prioritas, dan refleksi.

Pendidikan karakter memuat materi tentang serangkaian nilai-nilai positif yang dipandang tepat untuk mengembagkan karakter anak usia dini yang terdiri dari (1) Kecintaan Terhadap Tuhan YME berupa nilai-nilai yang didasarkan pada perilaku yang menunjukkan kepatuhan kepada perintah dan larangan Tuhan YME yang diterapkan dalam kehidupan sehari-hari; (2) toleransi dan cinta damai yaitu penanaman kebiasaan bersabar, tenggang rasa, dan menahan emosi dan keinginan; (3) disiplin yaitu nilai yang berkaitan dengan ketertiban dan keteraturan; (4) kejujuran yaitu sikap yang menunjukkan memahami kemampuan diri dan nilai harga diri; (5) percaya diri yaitu sikap yang menunjukkan memahami kemampuan diri dan nilai harga diri; (6) Mandiri yaitu perilaku yang tidak bergantung pada orang lain. Penanaman nilai ini bertujuan untuk membantu membiasakan anak menentukan, melakukan, dan memenuhi kebutuhan sendiri tanpa bantuan atau dengan bantuan yang seperlunya; (7) perilaku kreatif yaitu perilaku yang mendorong seseorang untuk dapat melahirkan sesuatu yang baru baik berupa gagasan, maupun karya baru dengan menekankan pada kemampuan mengkombinasikan, memecahkan atau menjawab masalah dan mencerminkan kemampuan operasional anak kreatif; (8) kerja keras yaitu nilai yang berkaitan dengan perilaku pantang menyerah berupa mengerjakan sesuatu hingga selesai dengan gembira; dan (9) tanggung jawab yaitu nilai yang terkait dengan kesadaran untuk melakukan dan menanggung segala sesuatunya.

\section{METODOLOGI}

Penelitian

bertujuan untuk mendeskripsikan kompetensi guru dalam pembelajaran berbasis pendidikan karakter pada anak usia dini. Penelitian menggunakan metoda deskriptif, dengan teknik purposive sampling pada guru-guru TK. Data dikumpulkan dengan menggunakan angket dan teknik wawancara, observasi dan studi dokumenter serta dianalisis dengan teknik kuantitatif dan kualitatif. Produk akhir penelitian ini adalah pengembangan program hipotetik untuk meningkatkan kompetensi guru dalam pembelajaran berbasis pendidikan karakter pada anak usia dini yang dirancang berdasarkan hasil penelitian berupa program pelatihan untuk mengembangkan kompetensi guru dalam pembelajaranran berbasis pendidikan karakter untuk anak usia dini.

Metode yang digunakan dalam penelitian ini adalah metode deskriftif, yang bertujuan untuk mendapatkan gambaran 
informasi tentang keadaan kompetensi guru dalam melaksanakan pembelajaran berbasis pendidikan karakter untuk anak usia dini. Data yang diperoleh adalah data tentang kompetensi guru di lapangan. Data kompetensi guru meliputi, kompetensi pedagogik, kompetensi kepribadian, kompetensi profesional dan kompetensi sosial dalam melaksanakan pembelajaran berbasis pendidikan karakter untuk anak usia dini.

Metode deskriptif digunakan karena akan menghasilkan data faktual yang diolah secara kuantitatif berdasarkan informasi statistik, dan data kualitatif yang dihasilkan berdasarkan hasil-hasil penelitian.Untuk lebih jelasnya tahap pelaksanaan penelitian digambarkan Adapun dalam penelitian ini tahapan-tahapan penelitian yang dilakukan mengikuti alur bagan berikut ini.

\section{HASIL DAN PEMB AHASAN}

Deskripsi hasil penelitian meliputi gambaran umum profil kompetensi guru TK yang secara nyata ada di lapangan berdasarkan jenis kelamin/gender, tingkat pendidikan terakhir dan pengalaman kerja. Profil kompetensi guru TK berdasarkan kompetensi pedagogik, kompetensi profesional, kompetensi kepribadian, dan kompetensi sosial. Deskripsi tingkat pendidikan dan pengalaman kerja terhadap kompetensi pedagogik, kompetensi profesional, kompetensi kepribadian dan kompetensi sosial. Deskripsi Lebih jelasnya mengenai hasil temuan penelitian dijelaskan berikut ini.

1. Gambaran Umum Profil Kompetensi Guru TK Berdas arkan Jenis Kelamin, Tingkat Pendidikan dan Pengalaman Kerja

a. Profil kompetensi guru TK berdasarkan jenis kelamin/gender
Gambaran jenis kelamin/gender guru TK diukur melalui angket, gambarannya ditampilkan pada grafik berikut.



Persentase Jenis Kelamin/Gender Guru TK

Dari grafik di atas menunjukan bahwa guru TK berdasarkan jenis kelamin/gender adalah mayoritas wanita yaitu sebanyak 101 orang atau sebesar $99,02 \%$ dan sebanyak 1 orang atau $0,98 \%$ adalah pria. Untuk lebih jelasnya dapat dilihat pada tabel 1.1.

Tabel 1.1

Frekwensi Jenis Kelamin/Gender

Guru TK

\begin{tabular}{|c|c|c|}
\hline $\begin{array}{c}\text { Jenis } \\
\text { Kelamin/Gender }\end{array}$ & Frekwensi & \% Profil \\
\hline Pria & 1 & $0.98 \%$ \\
\hline Wanita & 101 & $99.02 \%$ \\
\hline
\end{tabular}

\section{b. Profil kompetensi guru TK} berdasarkan tingkat pendidikan

Gambaran tingkat pendidikan guru TK diukur melalui angket ditampilkan pada grafik sebagai berikut. 


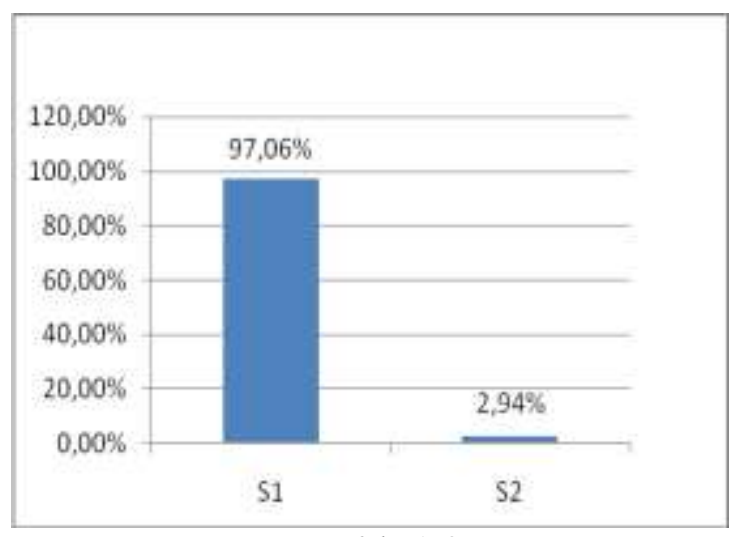

Grafik 1.2

Persentase Tingkat Pendidikan Guru TK

Dari grafik di atas menunjukan bahwa profil guru TK berdasarkan tingkat pendidikan dari angket diperoleh data mayoritas berpendidikan saat ini adalah pendidikan S1 sebanyak 98 orang atau $97.06 \%$, S2 sebanyak 3 orang atau $2.94 \%$, Untuk lebih jelasnya dapat dilihat pada tabel 1.2.

Tabel 1.2

Frekwensi Tingkat Pendidikan Guru $T K$

\begin{tabular}{|c|c|c|}
\hline $\begin{array}{c}\text { Tingkat } \\
\text { Pendidikan }\end{array}$ & Frekwensi & $\begin{array}{c}\% \\
\text { Profil }\end{array}$ \\
\hline S1 & 98 & $97,06 \%$ \\
\hline S2 & 3 & $2,94 \%$ \\
\hline
\end{tabular}

\section{c. Profil guru TK berdasarkan pengalaman kerja}

Gambaran pengalaman kerja guru TK diukur melalui angket ditampilkan pada grafik sebagai berikut.

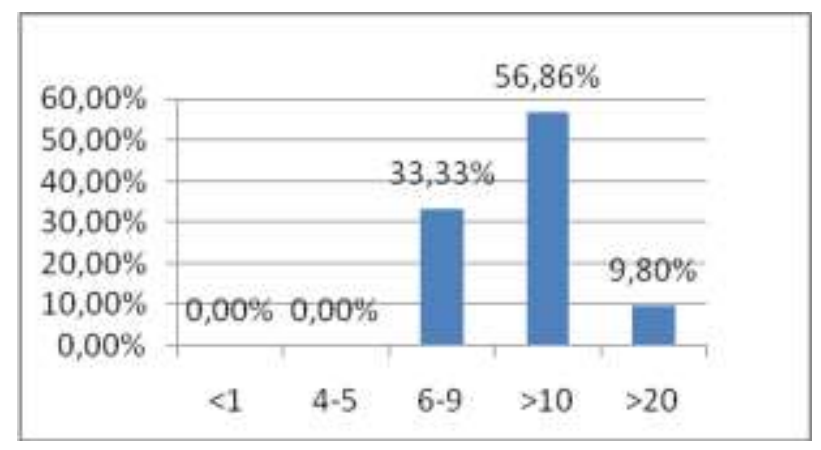

Grafik 1.3

Persentase Pengalaman Kerja Guru TK

Dari grafik 1.3 menunjukan bahwa guru TK mayoritas telah bekerja selama $>10$ tahun yaitu sebanyak 58 orang atau sebanyak 56,86\%, kemudian yang telah bekerja lebih dari 6-9 tahun sebanyak 34 orang atau 33,33\%, telah bekerja lebih dari $>20$ tahun sebanyak 10 orang atau sebesar 9,8\%, Untuk lebih jelasnya dapat dilihat pada tabel 1.3.

Tabel 1.3

Frekwensi Pengalaman Kerja Guru $T K$

\begin{tabular}{|c|c|c|}
\hline $\begin{array}{c}\text { Pengalaman } \\
\text { Kerja }\end{array}$ & Frekwensi & \% Profil \\
\hline$<1$ & 0 & $0.00 \%$ \\
\hline 2 s/d 5 & 0 & $0.00 \%$ \\
\hline 6 s/d 9 & 34 & $33.33 \%$ \\
\hline$>10$ & 58 & $56.86 \%$ \\
\hline$>20$ & 10 & $9.80 \%$ \\
\hline
\end{tabular}

2. Gambaran Umum Profil Kompetensi Guru TK Berdasarkan Kompetensi Pedagogik, Kompetensi Profesional, Kompetensi Kepribadian dan Kompetensi Sosial
a. Profil guru TK berdasarkan kompetensi pedagogik




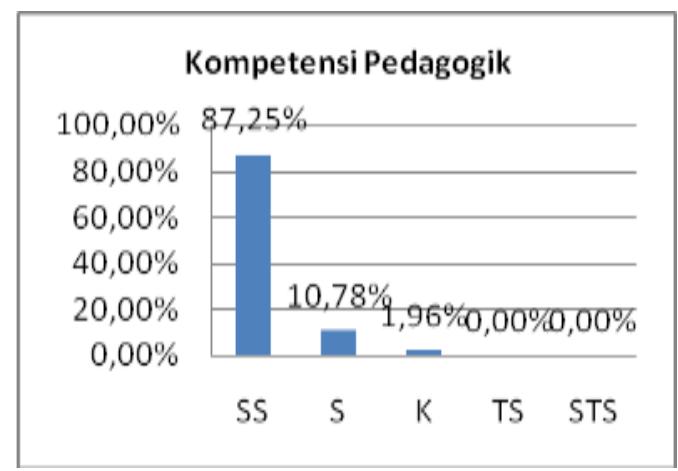

Grafik 1.4

Persentase Kompetensi Pedagogik Guru TK

Dari grafik 1.4 di atas menunjukan bahwa profil kompetensi pedagogik berdasarkan hasil jawaban angket, guru yang memilih alternatif jawaban Sangat Sesuai (SS) sebanyak 89 orang atau $87,25 \%$, yang memilih alternatif jawaban Sesuai (S) sebanyak 11 orang atau $10,78 \%$, yang memilih alternatif jawaban Kurang Sesuai (KS) sebanyak 2 orang atau 1,96\%. Untuk lebih jelasnya dapat dilihat pada tabel berikut.

Tabel 1.4

Frekwensi Profil Kompetensi Pedagogik Guru TK

\begin{tabular}{|l|c|c|}
\hline \multicolumn{1}{|c|}{$\begin{array}{c}\text { Alte rnatif } \\
\text { Jawaban }\end{array}$} & Frekwensi & \% Profil \\
\hline $\begin{array}{l}\text { Sangat Sesuai } \\
(\text { SS) }\end{array}$ & 89 & $87.25 \%$ \\
\hline Sesuai (S) & 11 & $10.78 \%$ \\
\hline $\begin{array}{l}\text { Kurang Sesuai } \\
\text { (KS) }\end{array}$ & 2 & $1.96 \%$ \\
\hline $\begin{array}{l}\text { Tidak Sesuai } \\
\text { (TS) }\end{array}$ & 0 & $0.00 \%$ \\
\hline $\begin{array}{l}\text { Sangat Tidak } \\
\text { Sesuai (STS) }\end{array}$ & 0 & $0.00 \%$ \\
\hline
\end{tabular}

\section{b. Profil guru TK berdasarkan kompetensi profesional}

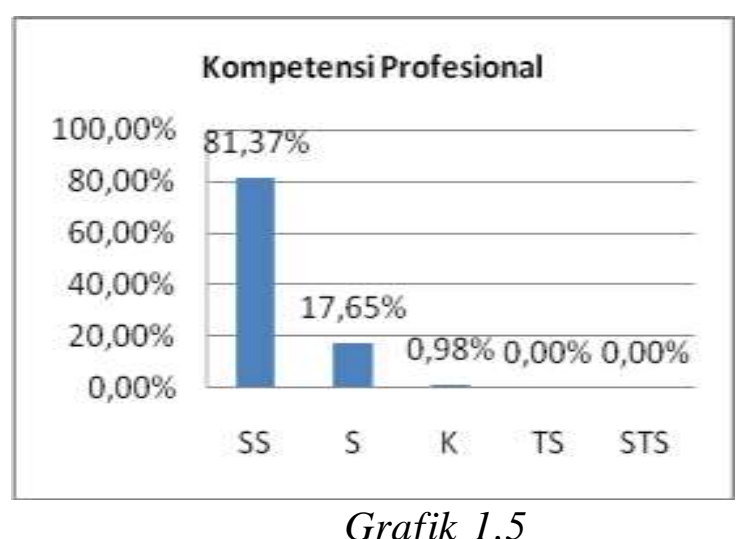

Persentase Kompetensi Profesional Guru $T K$

Dari grafik 1.5 di atas menunjukan bahwa profil kompetensi profesional berdasarkan hasil jawaban angket, guru yang memilih alternatif jawaban Sangat Sesuai (SS) sebanyak 83 orang atau $81,37 \%$, yang memilih alternatif jawaban Sesuai (S) sebanyak 18 orang atau $17,65 \%$ dan 1 orang atau $0,98 \%$ kurang sesuai. Untuk lebih jelasnya dapat dilihat pada tabel 1.5.

Tabel 1.5

Frekwensi Profil Kompetensi

Profesional Guru TK

\begin{tabular}{|c|c|c|}
\hline $\begin{array}{l}\text { Alternatif } \\
\text { Jawaban }\end{array}$ & Frekwensi & $\%$ Profil \\
\hline $\begin{array}{ll}\text { Sangat } & \text { Sesuai } \\
\text { (SS) } & \end{array}$ & 83 & $81.37 \%$ \\
\hline Sesuai (S) & 18 & $17.65 \%$ \\
\hline $\begin{array}{l}\text { Kurang Sesuai } \\
(\mathrm{KS})\end{array}$ & 1 & $0.98 \%$ \\
\hline $\begin{array}{ll}\text { Tidak } & \text { Sesuai } \\
\text { (TS) } & \end{array}$ & 0 & $0.00 \%$ \\
\hline $\begin{array}{l}\text { Sangat Tidak } \\
\text { Sesuai (STS) }\end{array}$ & 0 & $0.00 \%$ \\
\hline
\end{tabular}

c. Profil guru TK berdasarkan kompetensi kepribadian 


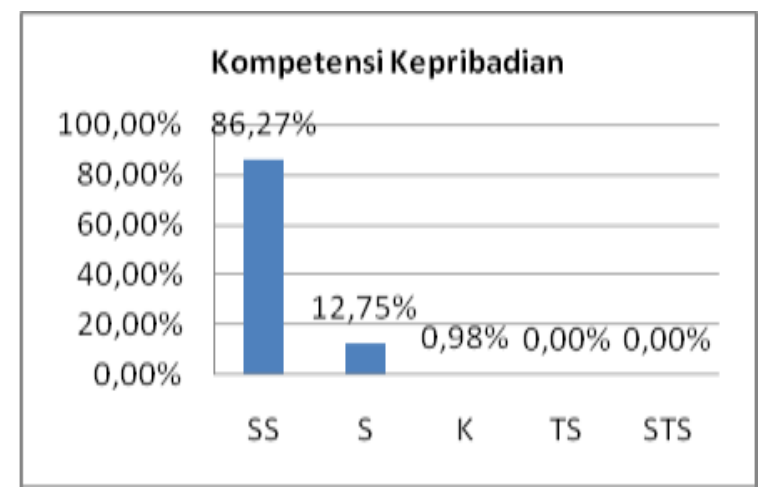

Grafik 1.6

Persentase Kompetensi Kepribadian Guru $T K$

Dari grafik 1.6 di atas menunjukan bahwa profil kompetensi kepribadian berdasarkan hasil jawaban angket, guru yang memilih alternatif jawaban Sangat Sesuai (SS) sebanyak 88 orang atau $86.27 \%$, yang memilih alternatif jawaban Sesuai (S) sebanyak 13 orang atau $12.75 \%$, yang memilih alternatif jawaban Kurang Sesuai (KS) sebanyak 1 orang atau 0,98\%. Untuk lebih jelasnya dapat dilihat pada tabel 1.6.

Tabel 1.6

Frekwensi Profil Kompetensi Kepribadian Guru TK

\begin{tabular}{|lr|r|r|}
\hline \multicolumn{2}{|c|}{$\begin{array}{c}\text { Alternatif } \\
\text { Jawaban }\end{array}$} & Frekwensi & \% Profil \\
\hline $\begin{array}{l}\text { Sangat Sesuai } \\
\text { (SS) }\end{array}$ & 88 & $86.27 \%$ \\
\hline Sesuai (S) & 13 & $12.75 \%$ \\
\hline $\begin{array}{l}\text { Kurang Sesuai } \\
(\mathrm{KS})\end{array}$ & 1 & $0.98 \%$ \\
\hline $\begin{array}{l}\text { Tidak Sesuai } \\
\text { (TS) }\end{array}$ & 0 & $0.00 \%$ \\
\hline $\begin{array}{l}\text { Sangat Tidak } \\
\text { Sesuai (STS) }\end{array}$ & 0 & $0.00 \%$ \\
\hline
\end{tabular}

\section{d. Profil guru TK berdasarkan kompetensi Sosial}

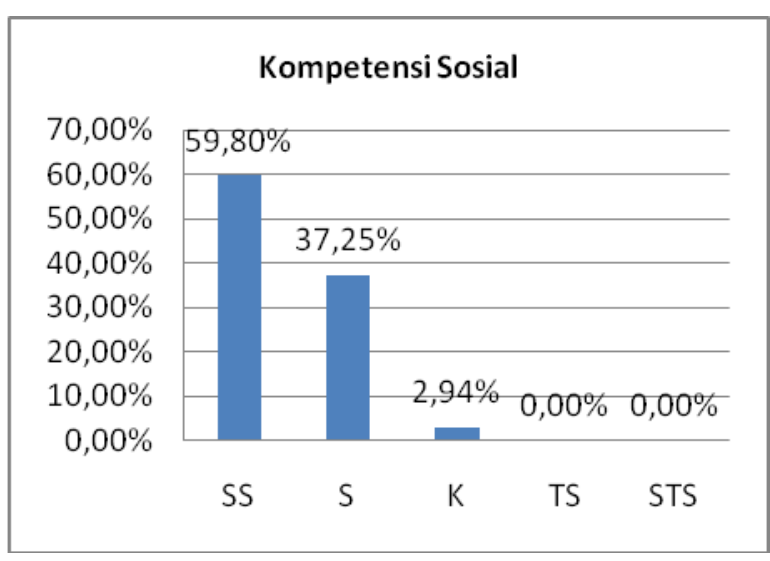

Grafik 1.7

Persentase Kompetensi Sosial Guru TK

Dari grafik 1.7 di atas menunjukan bahwa profil kompetensi kepribadian berdasarkan hasil jawaban angket, guru yang memilih alternatif jawaban Sangat Sesuai (SS) sebanyak 61 orang atau 59,80\%, yang memilih alternatif jawaban Sesuai (S) sebanyak 38 orang atau $37,25 \%$, yang memilih alternatif jawaban Kurang Sesuai (KS) sebanyak 3 orang atau 2,94\%. Untuk lebih jelasnya dapat dilihat pada tabel 1.7.

Tabel 1.7

Frekwensi Profil Kompetensi Sosial Guru TK

\begin{tabular}{|l|c|c|}
\hline \multicolumn{1}{|c|}{$\begin{array}{c}\text { Alternatif } \\
\text { Jawaban }\end{array}$} & Frekwensi & \% Profil \\
\hline $\begin{array}{l}\text { Sangat Sesuai } \\
\text { (SS) }\end{array}$ & 61 & $59.80 \%$ \\
\hline Sesuai (S) & 38 & $37.25 \%$ \\
\hline $\begin{array}{l}\text { Kurang Sesuai } \\
\text { (KS) }\end{array}$ & 3 & $2.94 \%$ \\
\hline $\begin{array}{l}\text { Tidak Sesuai } \\
\text { (TS) }\end{array}$ & 0 & $0.00 \%$ \\
\hline $\begin{array}{l}\text { Sangat Tidak } \\
\text { Sesuai (STS) }\end{array}$ & 0 & $0.00 \%$ \\
\hline
\end{tabular}

3. Deskripsi Tingkat Pendidikan dan Pengalaman Kerja Terhadap Kompetensi Pedagogik, Kompetensi Profesional, Kompetensi Kepribadian dan Kompetensi Sosial 
a. Tingkat pendidikan dan pengalaman kerja terhadap kompetensi pedagogik

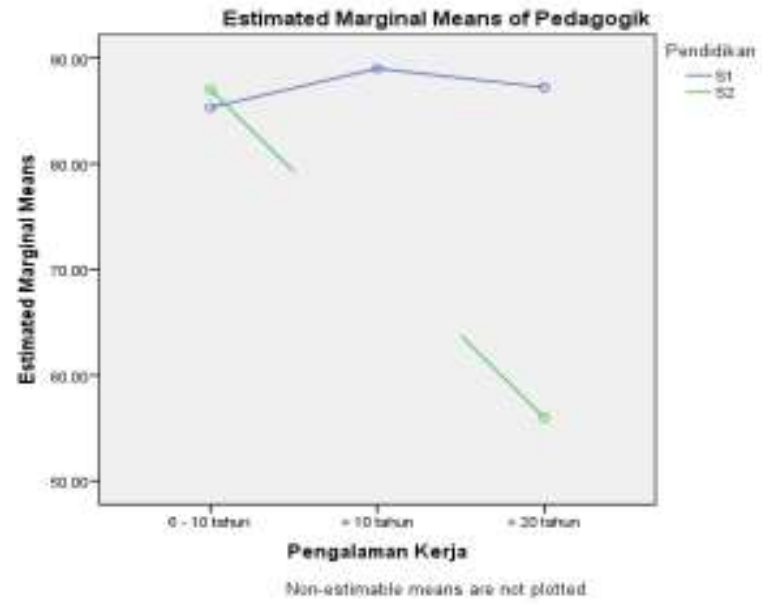

Grafik 1.8

Tingkat Pendidikan dan Pengalaman Kerja terhadap

Kompetensi Pedagogik

Untuk guru yang memiliki masa kerja $6-9$ tahun, dalam kompetensi pedagogik dengan tingkat pendidikan S2 lebih tinggi dari guru yang berlatar tingkat pendidikan S1, untuk guru dengan masa kerja > 10 tahun, tidak ada data yang berpendidikan $\mathrm{S} 2$, namun jika dibandingkan dengan masa kerja yang lebih sedikit ternyata bahwa guru yang masa kerja > 10 tahun memiliki kompetensi karakter yang lebih baik.

Adapun guru yang memiliki masa kerja > 20 tahun, dalam kompetensi pedagogik guru yang berlatar tingkat pendidikan S1 lebih tinggi dari guru yang berlatar tingkat pendidikan $\mathrm{S} 2$,

Grafik 1.10 menunjukan bahwa guru laki-laki dengan tingkat pendidikan S1 atau sederajat memiliki tingkat kompetensi

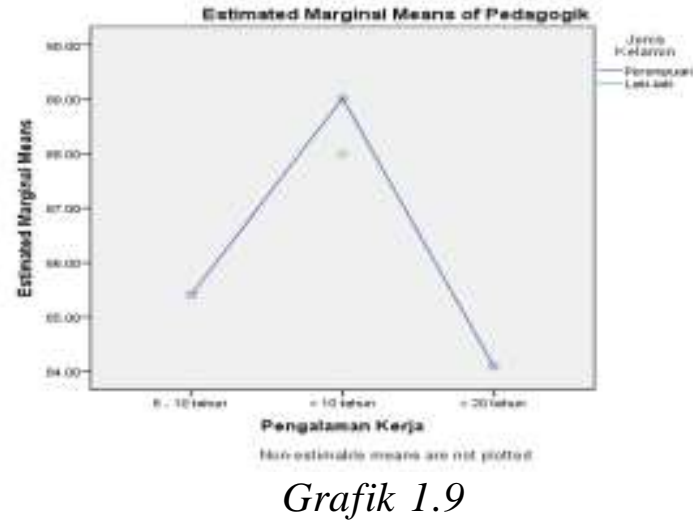

Gender dan Pengalaman Kerja terhadap Kompetensi Pedagog

Dari grafik 1.9 menunjukan bahwa guru laki-laki yang memiliki masa kerja $>10$ tahun memiliki tingkat kompetensi pedagogik yang lebih rendah daripada guru wanita dengan pengalaman kerja yang sama.

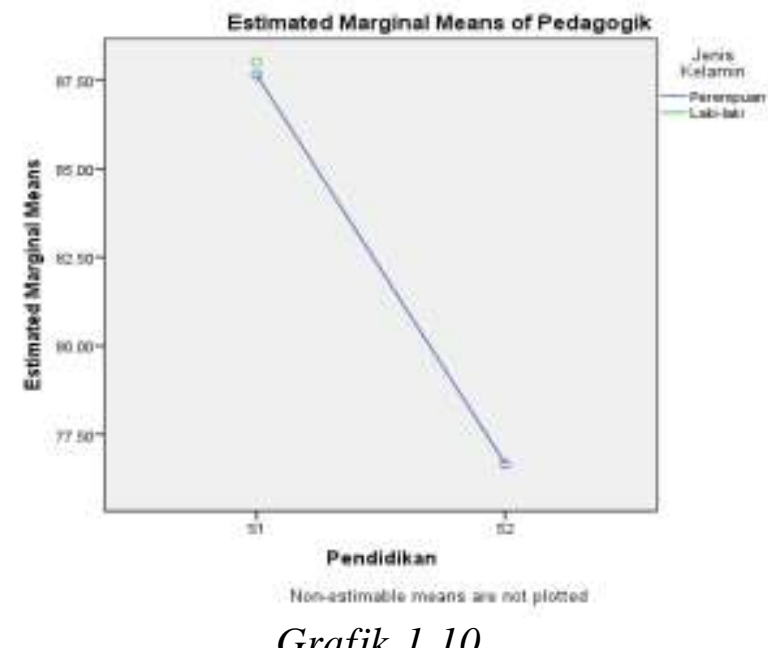

Gender dan Tingkat Pendidikan terhadap Kompetensi Pedagogik

pedagogik yang lebih tinggi dibanding guru wanita dengan tingkat pendidikan yang sama. 
b. Tingkat pendidikan dan pengalaman kerja terhadap kompetensi profesional

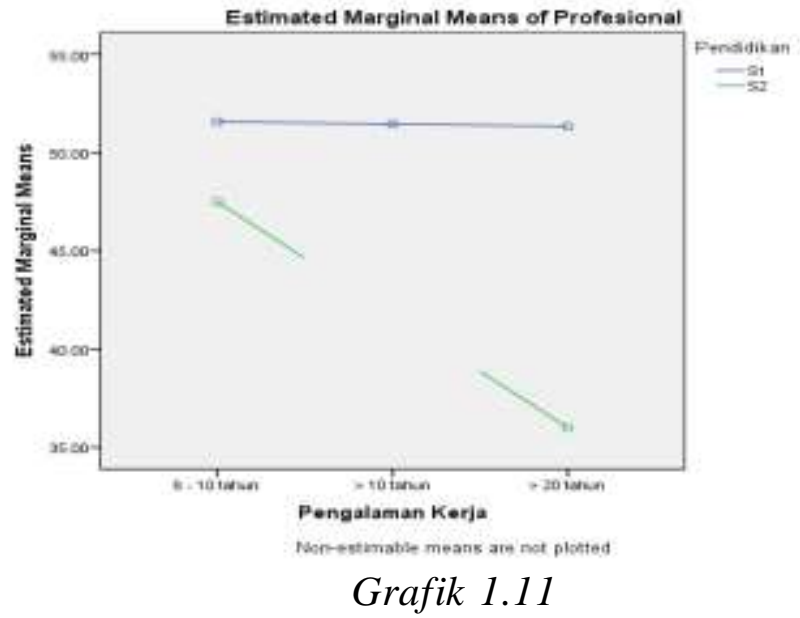

Tingkat Pendidikan dan Pengalaman Kerja terhadap Kompetensi Profesional

Dari grafik 1.11 diperoleh data ternyata memiliki kompetensi profesional bahwa dalam kompetensi profesional guru yang lebih tinggi dari S2 untuk masa kerja yang berlatar belakang pendidikan S1 yang sama.



Grafik 1.12

Gender dan Pengalaman Kerja terhadap Kompetensi Profesional

Dari grafik 1.12 untuk guru perempuan yang memiliki masa kerja yang sama dengan guru laki-laki memiliki kompetensi profesional lebih tinggi daripada kompetensi profesional guru laki-laki. c. Tingkat pendidikan dan pengalaman kerja terhadap kompetensi kepribadian 


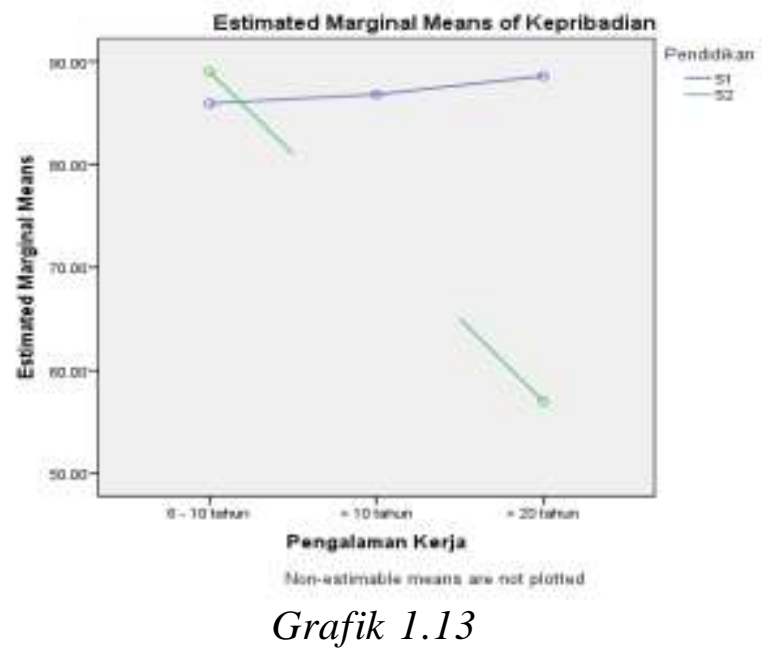

Tingkat Pendidikan dan Pengalaman Kerja terhadapKompetensi Kepribadian

Grafik 1.13 menggambarkan bahwa kompetensi kepribadian guru yang berlatar belakang tingkat pendidikan lebih tinggi tidak berbanding lurus dengan makin tingginya tinkat kompetensi. Untuk guru yang berlatar dengan masa kerja 6-9 tahun, menunjukan S2 lebih tinggi daripada guru yang berlatar tingkat pendidikan S1 untuk masa kerja yang sama. Tetapi tidak berlaku untuk masa kerja $>20$ tahun.

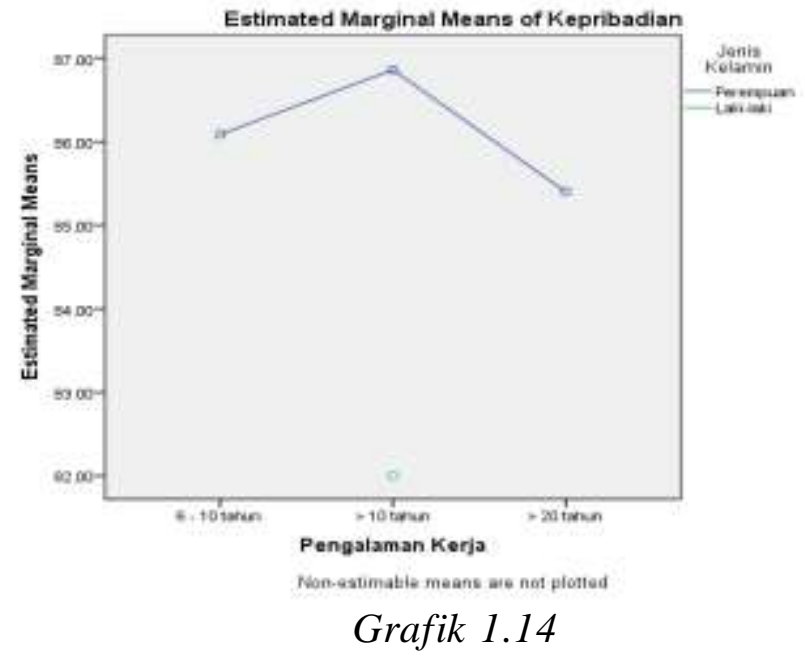

Gender dan Pengalaman Kerja terhadap Kompetensi Kepribadian

Dari grafik 1.14 diperoleh gambaran bahwa guru TK laki-laki yang memiliki masa kerja yang sama memiliki kompetensi kepribadian yang lebih rendah dibanding kompetensi kepribadian guru TK wanita. Seiring dengan lamanya masa kerja mencapai puncak kompetensi kepribadian di masa kerja lebih dari 10 tahun, tetapi akan menurun setelah masa kerja 20 tahun. 
PEDAGOGIA : Jurnal Ilmu Pendidikan

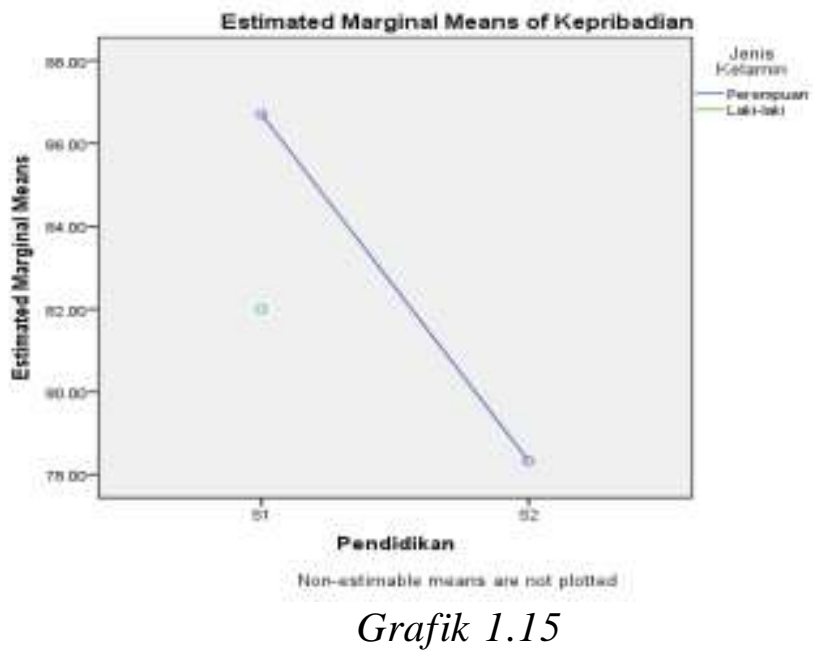

Gender dan Tingkat Pendidikan Terhadap Kompetensi Kepribadian

Grafik 1.15 menunjukkan guru TK berjenis kelamin pria memiliki tingkat kompetensi kepribadian yang lebih rendah dibanding guru TK dengan jenis kelamin wanita.

\section{d. Tingkat pendidikan dan pengalaman kerja tehadap kompetensi social}

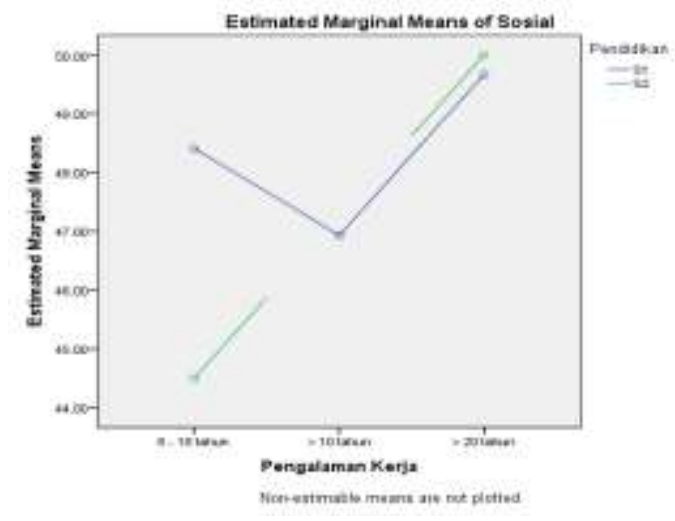

Grafik 1.16

Tingkat Pendidikan dan Pengalaman Kerja terhadap Kompetensi Sosial

Grafik 1.16 menunjukkan bahwa dalam kompetensi sosial, guru yang berlatar belakang tingkat pendidikan lebih tinggi umumnya memiliki kompetensi kepribadian yang lebih tinggi pula. Grafik di atas menunjukan bahwa guru yang berlatar tingkat pendidikan $\mathrm{S} 1$ cenderung memiliki kompetensi sosial yang menurun kemudian naik dengan semakin lama bekerja. 


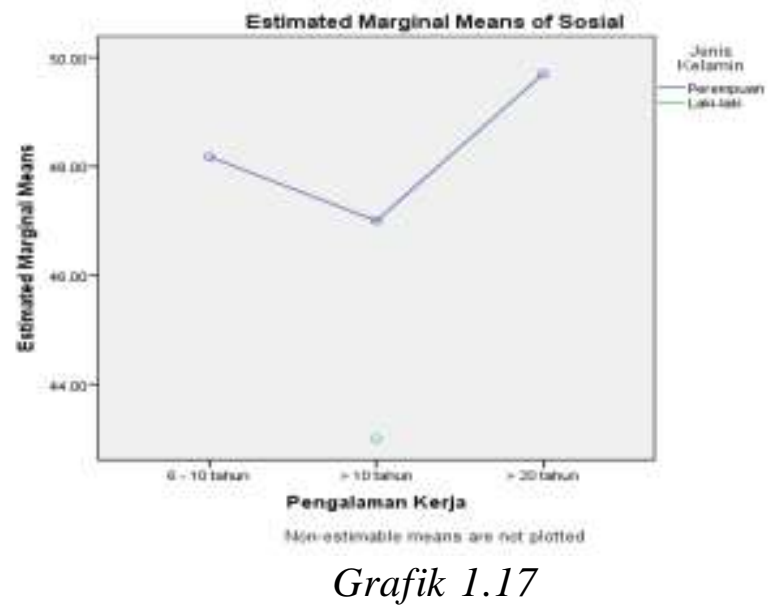

Pengalaman Kerja dan jenis kelamin terhadap Kompetensi Sosial

Grafik 1.17 menunjukkan bahwa lebih rendah dibanding guru TK berjenis untuk guru TK berjenis kelamin pria yang memiliki tingkat kompetensi sosial yang kelamin wanita.

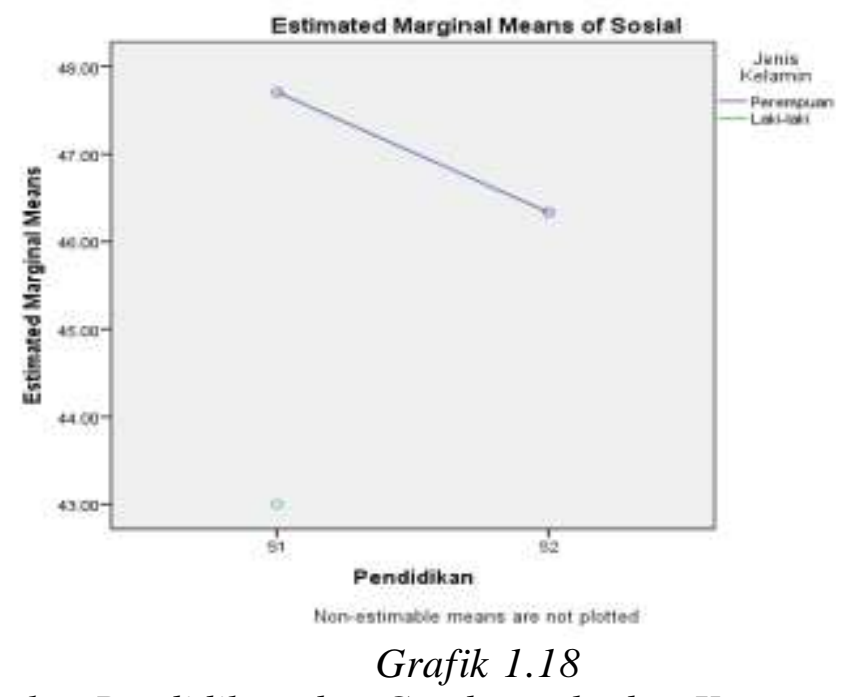

Tingkat Pendidikan dan Gender terhadap Kompetensi Sosial

Grafik 1.18 menggambarkan untuk guru dengan tingkat pendidikan sama yang berjenis kelamin laki-laki memiliki tingkat kompetensi sosial yang lebih rendah dari guru yang berjenis kelamin wanita.

\section{e. Tingkat pendidikan dan pengalaman kerja terhadap Kompetensi Guru Keseluruhan}




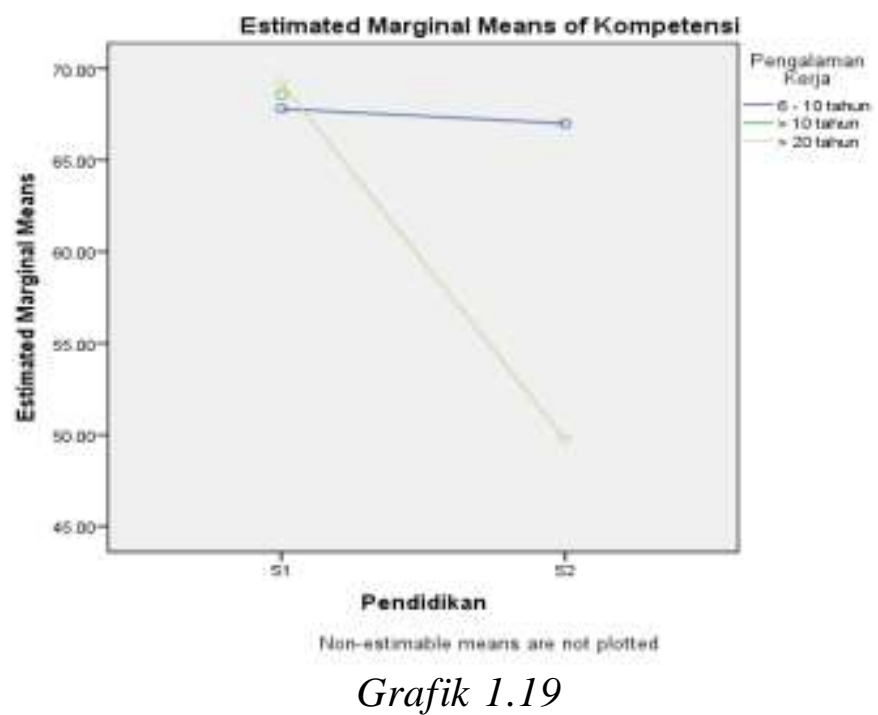

Tingkat Pendidikan dan Pengalaman Kerja terhadap Kompetensi Keseluruhan

Grafik $\quad 1.19$ menggambarkan tidak menunjukan bahwa semakin tinggi semakin lama bekerja maka kompetensi pula tingkat rata-rata kompetensi secara rata-rata keseluruhan akan semakin tinggi. keseluruhan.

Tingkat pendidikan yang semakin tinggi

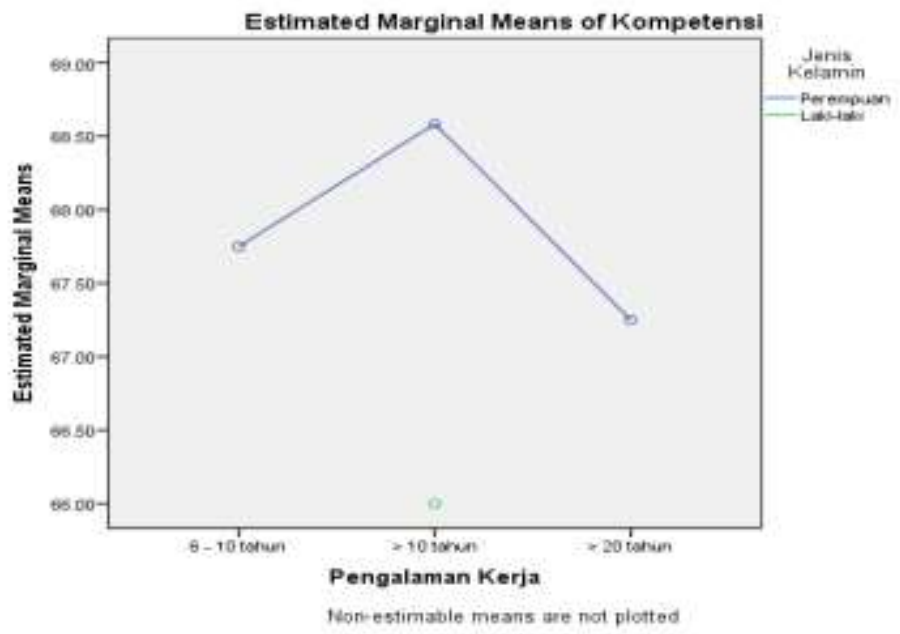

Grafik 1.20

Gender dan Pengalaman Kerja terhadap Kompetensi Keseluruhan

Pada grafik 1.20 menggambarkan bahwa guru TK pria yang memiliki masa kerja yang sama memiliki tingkat kompetensi yang lebih rendah dibanding guru TK wanita. Semakin lama masa kerja guru, grafik menunjukkan tingkat yang cenderung menaik, namun akan menurun jika masa kerja lebih dari 20 tahun. 


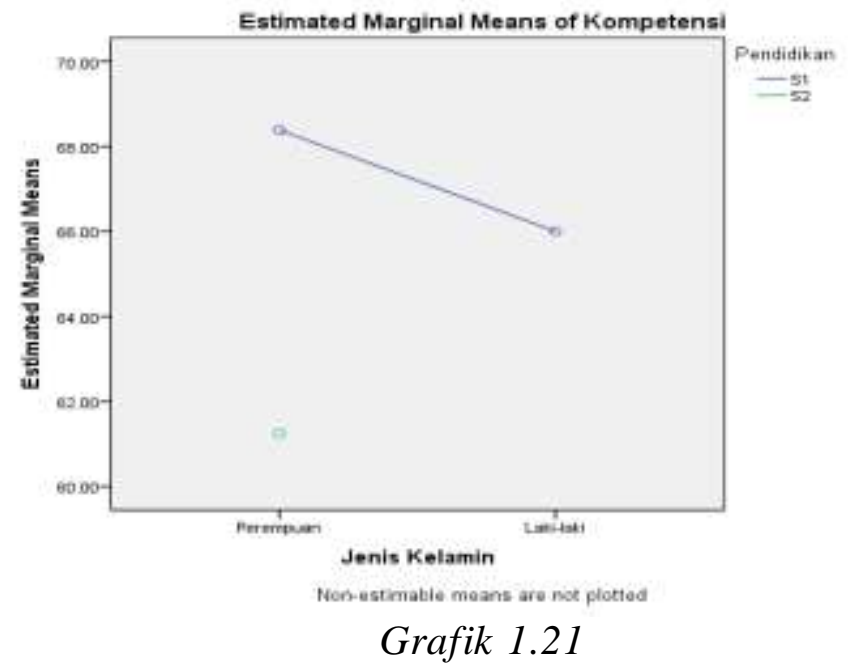

Gender dan Tingkat Pendidikan terhadap Kompetensi Keseluruhan

Grafik 1.21 menunjukkan bahwa guru TK pria yang berlatar pendidikan yang sama SMU/SMK atau sederajat memiliki tingkat kompetensi keseluruhan yang lebih rendah dibanding guru TK wanita.

\section{Pembahasan Hasil Penelitian}

\section{Kompetensi Guru TK yang Nyata di} Lapangan

Berdasarkan hasil angket dengan para guru di lapangan didapat keterangan bahwa kompetensi guru secara umum sudah memadai, akan tetapi dari hasil observasi di kelas masih terdapat ketidak sesuaian pelaksanaan pembelajaran dengan kompetensi guru yang diharapkan.

Berdasarkan hasil angket yang diberikan kepada para guru di lapangan didapat deskripsi bahwa kompetensi pedagogik memberi pengaruh yang paling tinggi dibanding kompetensi kepribadian, kompetensi profesional dan kompetensi sosial. Gambaran pengaruh tiap jenis kompetensi terhadap kompetensi guru secara keseluruhan dapat dilihat pada grafik berikut ini.

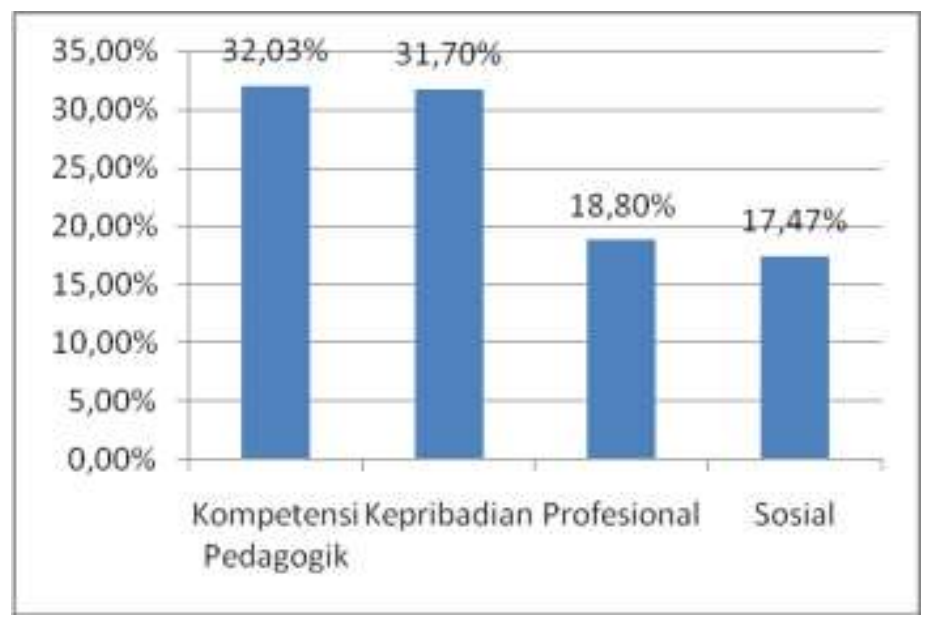

Grafik. 1.22

Gambaran Kompetensi Guru Secara Keseluruhan 
Dari grafik 1.22 di atas menunjukkan bahwa kompetensi pedagogik guru memberi pengaruh sebesar $32.03 \%$ terhadap kompetensi guru keseluruhan. Kompetensi kepribadian memberi pengaruh sebesar $31.70 \%$ terhadap kompetensi guru keseluruhan. Kompetensi profesional memberi pengaruh sebesar $18.80 \%$ terhadap kompetensi keseluruhan. Dan Kompetensi sosial memberi pengaruh sebesar $17.47 \%$ terhadap kompetensi keseluruhan.

\section{PENUTUP}

Berdasarkan hasil pembahasan penelitian yang telah dilakukan pada beberapa TK di Bandung mengenai kompetensi guru dalam pembelajaran berbasis pendidikan karakter untuk anak usia dini, didapat kesimpulan sebagai berikut.

1. Gambaran kompetensi guru di lapangan secara keseluruhan sudah cukup baik, dilihat dari hasil penelitian yaitu kompetensi pedagogik menunjukkan bahwa kompetensi pedagogik guru memberi pengaruh sebesar 32.03\% terhadap kompetensi guru keseluruhan. Kompetensi kepribadian memberi pengaruh sebesar $31.70 \%$ terhadap kompetensi guru keseluruhan. Kompetensi profesional memberi pengaruh sebesar $18.80 \%$ terhadap kompetensi keseluruhan. Dan Kompetensi sosial memberi pengaruh sebesar $17.47 \%$ terhadap kompetensi keseluruhan

2. Pelaksanaan pembelajaran berbasis pendidikan karakter oleh guru di lapangan belum menunjukkan pelaksanaan yang ideal, karena guru masih memisahkan antara proses pendidikan karakter dengan pelaksanaan pembelajaran
3. Kompetensi guru dalam pembelajaran berbasis pendidikan karakter pada anak usia dini perlu ditingkatkan melalui berbagai bentuk kegiatan yang dapat memfasilitasi guru untuk memahami secara lebih komprehenship pelaksanaan pendidikan karakter untuk anak usia dini yang terintegrasi dengan pembelajaran di TK dari tataran konseptual sampai kepada tataran praktek

\section{DAFTAR PUSTAKA}

Gutama, (2002). Kecerdasan Spiritual dalam Membentuk Perilaku Anak". Jurnal Ilmiah Anak Dini Usia. Vol. 02. Hal. 32-37.

Hamalik, Oemar. (2004). Pendidikan Guru Berdasarkan Pendekatan Kompetensi. Jakarta : Bumi Aksara

M. Surya, (2001) Psikologi Pembelajaran. Publikasi Jurusan Psikologi Pendidikan dan Bimbingan FIP UPI.

Mulyasa, E. (2006). Menjadi Guru Profesional Menciptakan Pembelajaran Kreatif dan Menyenangkan. Bandung : Remaja Rosdakarya

Mariyana, Rita. (2007). Pengembangan Program Pembelajaran Berbasis Bimbingan di Taman Kanak-Kanak. Tesis. Sekolah Pacsasarjana Universitas Pendidikan Indonesia. (Tidak diterbitkan)

Majid, Abdul dan Andayani, Dian. (2012). Pendidikan Karakter Perspektif Islam.Remaja Rosdakaya: Bandung 
Muhibbin Syah, (2001). Psikologi Pendidikan. Remaja Rosdakarya: Bandung.

Solehuddin, M. (1997). Konsep Dasar Pendidikan Prasekolah. Departemen Pendidikan dan Kebudayaan, Fakultas Ilmu
Pendidikan, Institut Keguruan dan Ilmu Pendidikan; Bandung.

Usman Uzer, (2004). MenjadiGuru Profesional. Remaja Rosdakarya; Bandung.

Yusuf, S (2001). Psikologi Perkembangan Anak dan Remaja. Bandung : Remaja Rosdakarya. 